\title{
Prognostic impact of high c-Met expression in ovarian cancer: a meta-analysis
}

\author{
Jung Han Kim ${ }^{1,},{ }^{\star}$, , Hyun Joo Jang ${ }^{1,}$, , Hyeong Su Kim ${ }^{1}$, Bum Jun Kim ${ }^{1,2}$ and Sung Ho Park ${ }^{3,}$, \\ 1. Department of Internal Medicine, Hallym University Medical Center, Hallym University College of Medicine, Seoul, Republic of Korea \\ 2. Department of Internal Medicine, National Army Capital Hospital, The Armed Forces Medical Command, Sungnam, Gyeonggi-Do, Republic of Korea \\ 3. Department of Obstetrics and Gynecology, Kangnam Sacred-Heart Hospital, Hallym University Medical Center, Hallym University College of Medicine, \\ Seoul, Republic of Korea. \\ * JH Kim and HJ Jang equally contributed to this work.
}

$\square$ Corresponding authors: Jung Han Kim and Sung Ho Park, Kangnam Sacred-Heart Hospital, Hallym University Medical Center, Hallym University College of Medicine, Seoul 07441, Republic of Korea. E-mail: harricil@hallym.or.kr (JHK), vth2000@hallym.or.kr (SHP)

( $)$ Ivyspring International Publisher. This is an open access article distributed under the terms of the Creative Commons Attribution (CC BY-NC) license (https://creativecommons.org/licenses/by-nc/4.0/). See http://ivyspring.com/terms for full terms and conditions.

Received: 2018.03.15; Accepted: 2018.07.17; Published: 2018.09.08

\begin{abstract}
High c-Met expression has been observed in epithelial ovarian cancer (EOC). However, its clinicopathological impacts remain controversial. We conducted this meta-analysis to evaluate the pathologic and prognostic significance of c-Met overexpression in patients with EOC. A systematic computerized search of the electronic databases PubMed, PMC, EMBASE, and Google scholar (up to April 2018) was carried out. From seven studies, 568 patients with EOC were included in the meta-analysis. Although there was no statistical significance, EOCs with c-Met overexpression tended to show higher FIGO stage (III-IV) (odds ratio $=2.18,95 \%$ confidence interval: $0.86-5.53$, P $=0.10$ ) and higher rate of lymph node metastasis (odds ratio $=3.05,95 \%$ confidence interval: $0.85-10.98, p=0.09$ ), compared with tumors with low c-Met expression. In terms of prognosis, patients with c-Met-high EOC showed significantly worse survival than those with c-Met-low tumor (hazard ratio $=2.11,95 \%$ confidence interval: 1.51-2.94, $\mathrm{p}<0.0001$ ). In conclusion, this meta-analysis indicates that high c-Met expression represents an adverse prognostic marker for patients with EOC.
\end{abstract}

Key words: c-Met expression; ovarian cancer; prognosis; meta-analysis; review

\section{Introduction}

Ovarian cancer is the leading cause of cancer-related death in woman worldwide, with the highest mortality rate of all gynecologic tumors [1-3]. Because the early stage of the disease is usually asymptomatic, two-thirds of patients with epithelial ovarian cancer (EOC) present at an advanced stage. Despite the recent advances in surgical techniques and chemotherapy modalities, the prognosis of EOC has not been improved [2,3]. The standard treatment for advanced EOC is optimal cytoreductive surgery followed by platinum-based chemotherapy. Although tumors usually show response to taxane plus platinum-based chemotherapy after surgical debulking, most patients with advanced stage eventually develop recurrent diseases and die of the cancer, with five-year survival rate lingering around $30 \%[4]$.

New molecular agents targeting vascular epithelial growth factor receptor (VEGFR) or poly ADP-ribose polymerase (PARP) have been introduced for the treatment of advanced EOC [5-7]. However, most tumors eventually develop resistance and their survival benefits are still disappointing. Therefore, there is a great need to identify novel therapeutic targets and develop more effective targeted drugs for patients with advanced EOC. Recently the MET axis has been proposed as a potential therapeutic target in various tumors, including EOC [8-10].

c-Met is the tyrosine kinase receptor for hepatocyte growth factor (HGF) and encoded by the 
protooncogene MET located at 7p31 locus of chromosome 7. The c-Met/HGF signaling pathway regulates multiple cellular functions, including differentiation, proliferation, angiogenesis, migration, and metastasis [11-14]. The aberrant activation of the c-Met/HGF pathway can be induced by various mechanisms, including MET mutation or amplification, c-Met transcriptional upregulation, and increased HGF secretion by the tumor microenvironment $[9,15,16]$. Recent data have shown that the c-Met/HGF pathway is abnormally regulated in a wide range of human cancers [15,16]. The enhanced expression of c-Met protein has been detected in many types of tumor such as breast cancer [17], non-small-cell lung cancer (NSCLC) [18], gastric cancer [19], head and neck cancer [20], cervix cancer [21], pancreatic cancer [22], hepatocellular carcinoma (HCC) [23], and renal cell carcinoma (RCC) [24]. The c-Met overexpression has been associated with poor prognosis as well as aggressive pathologic features in these tumors [17-24].

c-Met has also been overexpressed in a subset of EOC [25-34], but there have been conflicting data on the clinicopathological significance of high c-Met expression in patients with EOC. In several studies with a small number of EOC patients, c-Met overexpression has correlated with poor pathologic features or worse prognosis [28-32]. However, the pathological or prognostic impacts of high c-Met expression were not significant in other studies [30,32-34]. Therefore, we conducted this meta-analysis to gain a better insight into the pathologic and prognostic impacts of c-Met overexpression in patients with EOC. To our knowledge, this is the first meta-analysis to evaluate the clinicopathological significance of c-Met expression in EOC.

\section{Methods}

\section{Publication searching strategy}

This meta-analysis was performed in accordance with the Preferred Reporting Items for Systematic Reviews and Meta-Analyses (PRISMA) guidelines [35]. A systematic computerized search of the electronic databases PubMed, PMC, EMBASE, and Google scholar (up to April 2018) was carried out. The following search terms were used to identify relevant publications: "c-Met" or "Met" or "hepatocyte growth factor receptor", and "ovarian cancer." The related articles function in the PubMed was also used to find all relevant articles. The computerized search was supplemented with a manual search of the primary articles cited in the retrieved review articles. The titles and abstracts of the retrieved studies were initially scanned to exclude irrelevant papers. Then, the potentially relevant articles were reviewed in full text, further excluding those that did not meet the inclusion criteria of this meta-analysis.

\section{Inclusion criteria}

Eligible studies should meet the following inclusion criteria: (i) patients had a pathological diagnosis of epithelial ovarian cancer; (ii) pathological features [the International Federation of Gynecology and Obstetrics (FIGO) stage and/or lymph node (LN) metastasis] or overall survival (OS) were analyzed according to c-Met expression status; (iii) odds ratio (OR) with 95\% confidence interval (CI) for pathological features or (hazard ratio) HR with 95\% CI for OS were provided or could be estimated from the data provided; (iv) articles were published in English.

\section{Data extraction}

The required data were collected independently by two investigators (BJK and SHP). If these two authors did not agree, the other investigator (JHK) was consulted to resolve the discrepancies.

The following data were recorded from all eligible studies: the first author's name; publication year; country; number of patients; treatment; histology; FIGO stage; LN status; methods to test c-Met expression, antibody for immunohistochemistry (IHC); cutoff values adopted to define c-Met overexpression; HR with 95\% CI for OS and OR with $95 \%$ CI for pathological features.

\section{Statistical analyses}

Statistical values used in the meta-analysis were directly obtained from the original articles or were indirectly calculated from the given data. If OR or HR with $95 \%$ CI were not reported directly, the Engauge Digitizer software was used to estimate the needed data from the results and Kaplan-Meier curves. The strength of the association between c-Met overexpression and pathological features (FIGO stage and LN metastasis) was shown as ORs and their 95\% CIs. The effect size of OS was pooled through HR and 95\% CI. The RevMan version 5.3 was used to combine data and report outcomes. The heterogeneity across studies was tested by using the chi-square-based Cochran's Q statistic and the $I^{2}$ inconsistency test. The fixed-effects model (Mantel-Haenszel method) was selected for pooling homogeneous outcomes when $\mathrm{p}$ $\geq 0.1$ or $I^{2} \leq 50 \%$, whereas the random-effects model (DerSimonian-Laird method) was applied for pooling heterogeneous outcomes when $\mathrm{p}<0.1$ or $I^{2}>50 \%$. All reported $P$-values were two-sided, with $p<0.05$ defined as statistically significant.

The possibility of publication bias was assessed with a visual inspection of the funnel plot [36]. The 
statistical methods for detecting funnel plot asymmetry were the rank correlation tests of Begg and Mazumdar and the Egger's regression asymmetry test [36,37].

\section{Results}

\section{Results of search}

Figure 1 shows flow diagram of search process. A total of 117 relevant studies were initially retrieved, but 107 of them were excluded after screening the titles and abstracts. Of the remaining 10 potentially eligible studies, three were further excluded by the inclusion criteria: they had no data for comparison of pathological features or survival [25-27]. Finally, seven studies were included in the meta-analysis [28-34].

\section{Characteristics of the included studies}

Table 1 summarizes the main characteristics and clinicopathological findings of the seven included studies. All the studies were performed retrospectively. From the seven studies, 568 patients were included in the meta-analysis. All patients underwent cytoreductive surgery and most of them received adjuvant platinum-based chemotherapy. Two studies had patients only with clear cell carcinoma [30,32].

\section{c-Met expression assignation}

All seven studies used IHC to assess c-Met expression status. The criteria for c-Met overexpression were briefly summarized in Table 1.

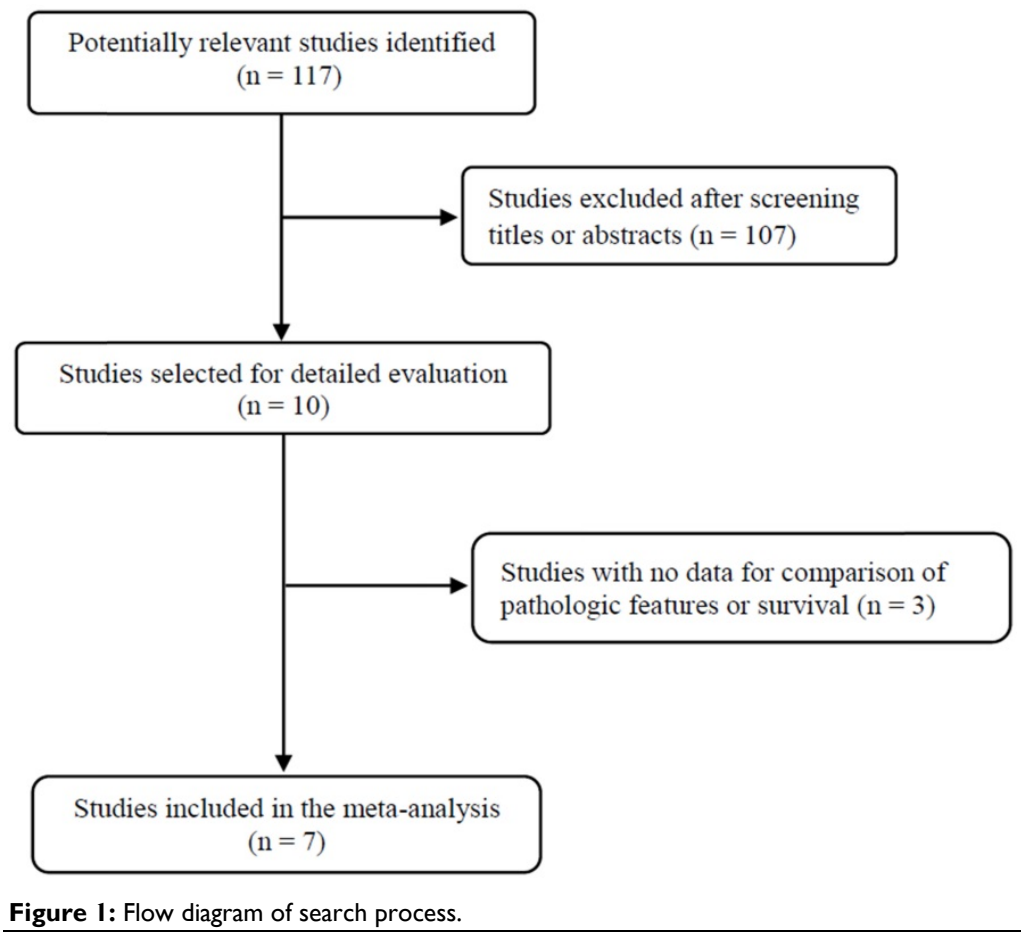

There was a significant heterogeneity among the criteria used to dichotomize c-Met status (low or high) in the six studies [28-30,32-34]. The remaining one study did not describe the cutoff value for c-Met overexpression [31]. The rates of high c-Met expression varied from $10.9 \%$ [29] to $76.6 \%$ [31].

\section{Impact of high c-Met expression on pathological features}

From four studies [30-33], 329 patients were included in the meta-analysis of ORs with $95 \%$ CIs for FIGO stage. The result showed a significant heterogeneity among studies $\left(X^{2}=7.89, \mathrm{p}=0.05, I^{2}=\right.$ $62 \%)$ and the random-effects model was used. Compared with EOCs with low expression, tumors with c-Met overexpression showed higher FIGO stage (III-IV) with no statistical significance (OR $=2.18,95 \%$ CI: 0.86-5.53, $\mathrm{p}=0.10$ ) (Figure 2A).

Four studies including 264 patients were analyzed for the effect of c-Met overexpression on the LN metastasis [28,30-32]. The random-effects model was also selected because there was a significant heterogeneity across the studies $\left(X^{2}=7.96, p=0.05, I^{2}\right.$ $=62 \%)$. Compared with tumors showing low c-Met expression, EOCs with high c-Met expression tended to show higher rate of $\mathrm{LN}$ metastasis (OR $=3.05,95 \%$ CI: 0.85-10.98, $\mathrm{p}=0.09$ ) (Figure 2B).

\section{Impact of high c-Met expression on overall survival}

From six studies [28-30,32-34], 521 patients were included in the meta-analysis of HRs with 95\% CIs for OS. Patients with c-Met-high EOC showed significantly worse OS than those with c-Met-low tumor $(\mathrm{HR}=2.11,95 \%$ CI: 1.51-2.94, $\mathrm{p}<0.0001$ ) (Figure 3). The fixed-effect model was selected because there was no significant heterogeneity across the studies $\left(X^{2}=4.88, \mathrm{p}=0.43, I^{2}=\right.$ $0 \%)$.

\section{Publication bias}

Begg's funnel plots and Egger's test showed no significant evidence of substantial publication biases for FIGO stage (Begg's $p=0.145$, Egger's $p=0.141)$, LN metastasis (Begg's $p=0.154$, Egger's $p$ $=0.102)$, and OS (Begg's p = 0.174, Egger's $\mathrm{p}=0.306)$ (Figure $4 \mathrm{~A}-4 \mathrm{C})$.

\section{Discussion}

In this meta-analysis, we evaluated the pathologic and prognostic impacts of c-Met overexpression in patients with EOC. The results failed to show a statistically 
significant correlation between c-Met status and major pathologic features (FIGO stage and LN metastasis).
However, high c-Met expression was significantly associated with a poor prognosis.

Table 1. Summary of the seven included studies

\begin{tabular}{|c|c|c|c|c|c|c|c|c|}
\hline $\begin{array}{l}\text { First author } \\
\text { (year) [ref] }\end{array}$ & Country & Histology & Methods, antibody, & $\begin{array}{l}\text { No. of } \\
\text { patients }\end{array}$ & Criteria for c-Met overexpression & $\begin{array}{l}\text { High c-Met } \\
\text { expression (\%) }\end{array}$ & $\begin{array}{l}\text { FIGO stage (III-IV) } \\
\text { (yes : no) }\end{array}$ & $\begin{array}{l}\text { LN metastasis } \\
\text { (yes : no) }\end{array}$ \\
\hline $\begin{array}{l}\text { Ayhan } \\
(2005) \text { [28] }\end{array}$ & Turkey & $\begin{array}{l}\text { Serous (24) } \\
\text { Mucinous (7), } \\
\text { Endometroid } \\
(6) \\
\text { Clear cell (1) } \\
\text { UD (3) }\end{array}$ & $\begin{array}{l}\text { IHC with whole } \\
\text { slides, } \\
\text { Polyclonal rabbit } \\
\text { anti-c-Met Ab }\end{array}$ & 41 & $\geq 20 \%$ of cancer cells & $25(60.9 \%)$ & NA & $\begin{array}{l}24(96 \%): 7(43.8 \%) \\
p=0.008\end{array}$ \\
\hline $\begin{array}{l}\text { Sawada } \\
\text { (2007) [29] }\end{array}$ & USA & $\begin{array}{l}\text { Serous (114) } \\
\text { Endometroid } \\
(11) \\
\text { Clear cell (10), } \\
\text { Mucinous (3) }\end{array}$ & $\begin{array}{l}\text { IHC with TMA, } \\
\text { Anti-c-Met (3D4) }\end{array}$ & 138 & $\begin{array}{l}\text { No staining }(0) \text {, weak }(1) \text {, } \\
\text { moderate }(2) \text {, and strong }(3) \\
\text { (c-Met overexpression: strong } \\
\text { staining: } 3+\text { ) }\end{array}$ & $15(10.9 \%)$ & NA & NA \\
\hline $\begin{array}{l}\text { Yamamoto } \\
\text { (2011) [30] }\end{array}$ & Japan & Clear cell & $\begin{array}{l}\text { IHC with TMA, } \\
\text { CONFIRM anti-Total } \\
\text { c-Met (SP44) }\end{array}$ & 90 & $\begin{array}{l}\text { Moderate }(2+) \text { or strong }(3+) \text { when } \\
\text { complete cytoplasmic staining in } \\
\geq 10 \% \text { of cancer cells }\end{array}$ & $20(22.2 \%)$ & $\begin{array}{l}10(50 \%): 21(30 \%) \\
p=0.097\end{array}$ & $\begin{array}{l}2(20 \%): 10(20.8 \%) \\
p=0.953\end{array}$ \\
\hline $\begin{array}{l}\mathrm{Li} \\
(2014)[31]\end{array}$ & China & $\begin{array}{l}\text { Serous (30) } \\
\text { Mucinous (10) } \\
\text { Endometroid } \\
\text { (7) }\end{array}$ & $\begin{array}{l}\text { IHC with whole slides } \\
\text { Primary monoclonal } \\
\mathrm{Ab}\end{array}$ & 47 & Not described & $36(76.6 \%)$ & $\begin{array}{l}32(88.9 \%): 5(45.5 \%) \\
p=0.008\end{array}$ & $\begin{array}{l}9(25 \%): 9(81.8 \%) \\
p=0.002\end{array}$ \\
\hline $\begin{array}{l}\text { Wang } \\
\text { (2015) [32] }\end{array}$ & China & Clear cell & $\begin{array}{l}\text { IHC with whole } \\
\text { slides, } \\
\text { Polyclonal rabbit } \\
\text { anti-c-Met Ab, }\end{array}$ & 86 & $\begin{array}{l}\text { Intensity: no pigmentation }(0) \text {, } \\
\text { light yellow (1), buffy (2), brown } \\
\text { (3) } \\
\text { Proportion of staining area: }<5 \% \\
\text { (0), } 5-25 \%(1), 26-50 \%(2), 51-75 \% \\
\text { (3), and } \geq 75 \%(4) \\
\text { (c-Met overexpression: intensity } \\
\text { score x proportion score } \geq 5 \text { ) }\end{array}$ & $60(69.8 \%)$ & $\begin{array}{l}21(35 \%): 5(19.2 \%) \\
p=0.144\end{array}$ & $\begin{array}{l}51(87.9 \%): 23(88.5 \%) \\
p=1.000\end{array}$ \\
\hline $\begin{array}{l}\text { Battista } \\
(2016)[33]\end{array}$ & Germany & $\begin{array}{l}\text { Serous (82) } \\
\text { Mucinous (14) } \\
\text { Endometroid } \\
(5) \\
\text { Clear cell (2) } \\
\text { Mixed (3) }\end{array}$ & $\begin{array}{l}\text { IHC with whole } \\
\text { slides, } \\
\text { Polyclonal goat } \\
\text { anti-c-Met Ab }\end{array}$ & 106 & $\begin{array}{l}\text { No staining ( } 0 \text { ), definite } \\
\text { cytoplasmic and/or equivocal } \\
\text { membrane staining (1), } \\
\text { unequivocal membrane staining } \\
\text { with mild to moderate intensity } \\
\text { (2), and strong and complete } \\
\text { membranous staining ( } 3 \text { ) } \\
\text { (c-Met overexpression: } 2+\text { or } 3+\text { ) }\end{array}$ & $22(20.8 \%)$ & $\begin{array}{l}15(68.2 \%): 63(75 \%) \\
p=0.344\end{array}$ & NA \\
\hline $\begin{array}{l}\text { Puvanenthiran } \\
\text { (2018) [34] }\end{array}$ & UK & $\begin{array}{l}\text { Serous (51) } \\
\text { Non-serous (9) }\end{array}$ & $\begin{array}{l}\text { IHC, } \\
\text { mouse anti-c-Met }\end{array}$ & 60 & $>5 \%$ of tumor cells & $13(21.7 \%)$ & NA & NA \\
\hline
\end{tabular}

A.

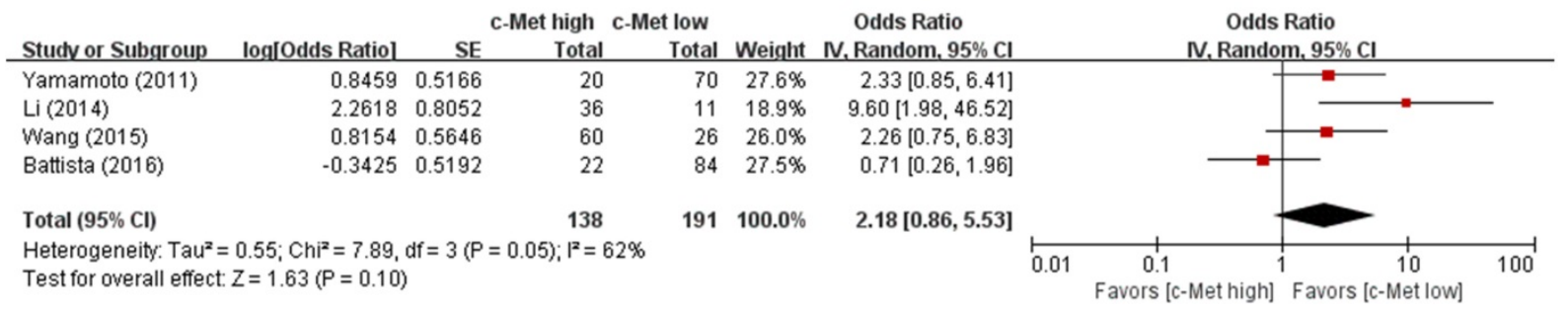

B.

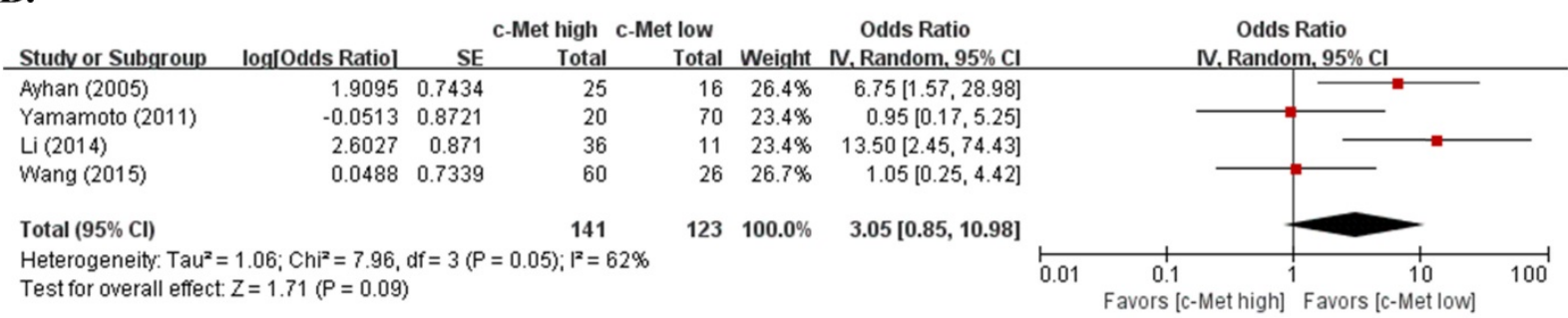

Figure 2: Forest plots of odds ratios for FIGO stage (A) and lymph node metastatsis (B). 


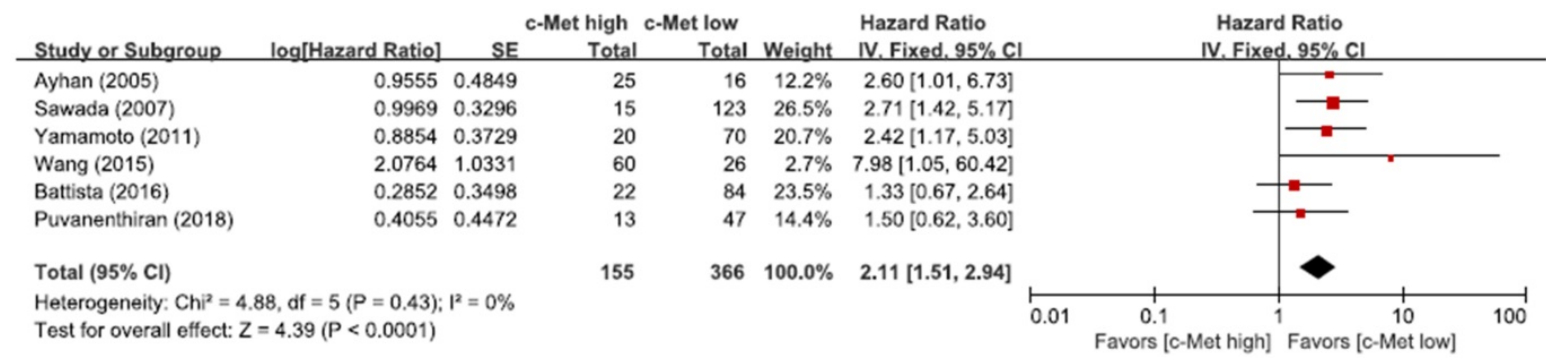

Figure 3: Forest plot of hazard ratios for overall survival.

A.

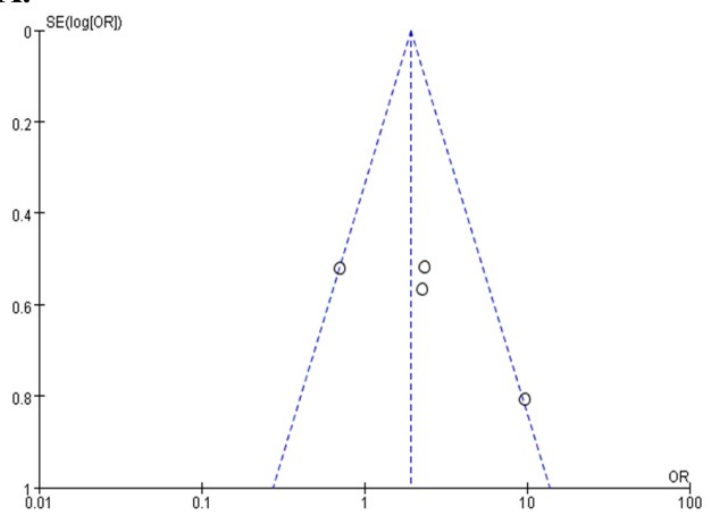

B.

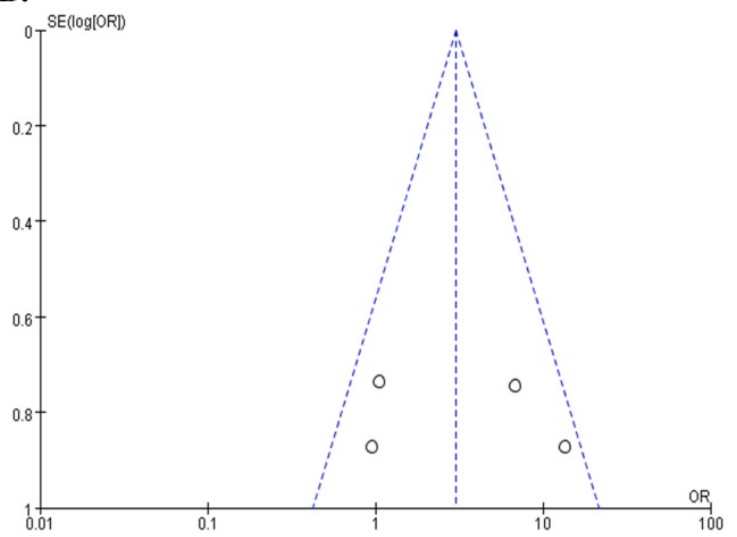

C.

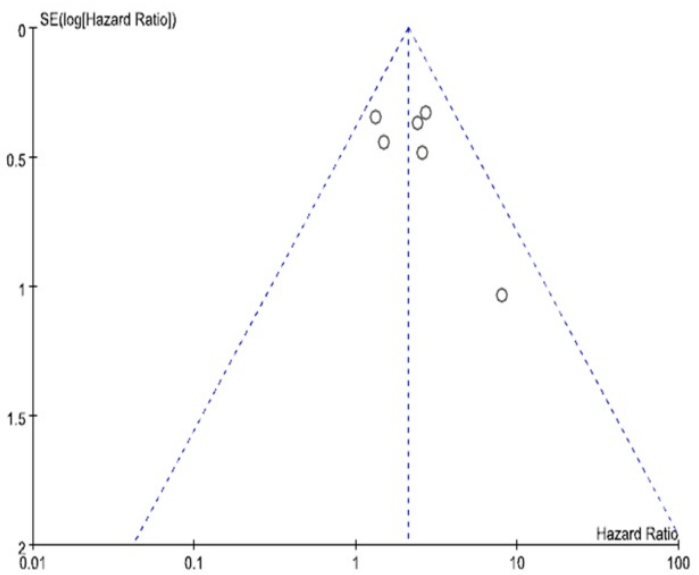

Figure 4: Funnel plots for publication bias regarding FIGO stage (A), lymph node metastasis (B), and overall survival (C).
The role of MET activation in the carcinogenesis and progression has been well established in many tumor types $[15,16]$. Mechanisms of MET activation include nucleotide variations, mutations, amplification, and overexpression of both c-Met and HGF protein $[9,15,16,38]$. MET amplification has been detected in up to $3.5 \%$ of EOCs $[30,38]$ and nucleotide variations in $7.4 \%$ [38]. c-Met overexpression is the most frequently observed alteration in EOCs, presenting in up to $77 \%[31,32]$. Studies in patients with EOCs reported that high c-Met expression correlated with clinicopathological parameters indicative of poor prognosis, such as histologic grade [28,31], LN metastasis [28, 31], FIGO stage [30,31], and shorter OS [28-30,32]. However, the pathological or clinical impacts of c-Met expression were not consistent across the studies [30,32-34]. For example, Battista et al. evaluated c-Met status in a cohort of consecutive patients $(n=106)$ with EOC and failed to find significant prognostic impacts of c-Met overexpression in regard to histologic grade, FIGO stage, and OS [33]. These contrary results may stem from a small number of patients in each study and histological heterogeneity of EOCs. In addition, most studies used different IHC criteria for c-Met overexpression. Multiple methods, such as IHC, Western blot, fluorescence in situ hybridization, and reverse transcription-polymerase chain reaction are currently used to assess c-Met status. While IHC is a readily available and easily adoptable assay method, there are wide differences in the IHC criteria for c-Met status. The discrepancies in the clinicopathological impacts of c-Met among studies might be due to the different IHC criteria for c-Met overexpression [28-34].

In the current meta-analysis, we included studies comparing two major pathological features (FIGO stage and LN metastasis) and cancer-specific survival outcome according to the c-Met expression status. Although there was no statistical significance in the meta-analysis with a small number of studies, EOCs with c-Met overexpression tended to show higher FIGO stage (III-IV) $(\mathrm{OR}=2.18, \mathrm{p}=0.10)$ and higher rate of $\mathrm{LN}$ metastasis $(\mathrm{OR}=3.05, \mathrm{p}=0.09)$, compared 
to tumors with low c-Met expression. In terms of prognosis, patients with c-Met-high EOC showed significantly worse OS than those with c-Met-low tumor $(\mathrm{HR}=2.11, \mathrm{p}<0.0001)$. Our findings indicate that high c-Met expression represent an adverse prognostic marker for patients with EOC. Some studies reported that c-Met overexpression in EOCs was predominantly associated with type I (low-grade serous, emdometroid, clear cell, and mucinous) tumor, compared with type II (high-grade serous) tumor $[29,30,33]$. These results may due to the fact that c-Met has cross-talks with several pathways such as PI3K/Akt, BRAF, and RAS-MAPK that is known to impact the development of type I EOC [39-43]. Gene expression profiling studies found that type I tumors were associated with mutations in KRAS, BRAF, and PTEN, whereas type II tumors correlated strongly with TP53 mutations [39]. In this meta-analysis with a small number studies included, however, we could not perform subgroup-analysis according to the histological subtypes of EOC.

Several meta-analyses have also demonstrated that high c-Met expression is an adverse prognostic marker in other tumor types [17-24]. Because of its ubiquitous role in cancer, the inhibition of c-Met/HGF pathway may provide an effective therapeutic strategy for cancers showing MET activation $[9,10,44]$. Based on the scientific rationale to target c-Met protein, several MET pathway inhibitors have been investigated for a variety of cancers, including RCC, HCC, and NSCLC [8,34,45-48]. Cabozantinib is an oral inhibitor of tyrosine kinases including MET and VEGFR-2. In a randomized phase 3 trial of patients with advanced RCC who progressed after previous VEGFR tyrosine-kinase inhibitor treatment, cabozantinib significantly prolonged OS (median 21.4 vs. 16.5 months, $\mathrm{HR}=0.66, \mathrm{p}=0.00026$ ) and progression-free survival (median 7.4 vs. 3.9 months, $\mathrm{HR}=0.51, \mathrm{p}<0.0001)$, compared with everolimus, mTOR inhibitor [47]. Tivantinib, an oral selective c-Met receptor tyrosine kinase inhibitor, showed promising outcomes as a second-line therapy in a randomized phase II trial of patients with advanced HCC [45]. In the post hoc analysis of the c-Met-high subgroup, patients treated with tivantinib showed significantly longer time-to-progression (median 2.7 vs. 1.4 months, $\mathrm{HR}=0.43, \mathrm{p}=0.03$ ) and OS (median 7.2 vs. 3.8 months, $\mathrm{HR}=0.38, \mathrm{p}=0.01$ ), compared with those with placebo. In addition, in a recent randomized phase III trial of patients with advanced NSCLC, the survival benefits of tivatinib in combination with erlotinib was also significantly associated with c-Met overexpression [48]. Therefore, patients with tumor showing c-Met overexpression might be good candidates for treatment with a MET inhibitor.

MET inhibitors are also under active investigation for patients with advanced EOC [49-51]. Tang et al. found that c-Met overexpression enhanced the survival of cancer cells and increased resistance to chemotherapeutic agents (cisplatin and paclitaxel) [49]. Also inhibition of c-Met by small interfering RNA blocked the acquired anoikis resistance and restored chemosensitivity in three-dimensional cell cultures. In addition, Marchion et al. reported that targeted inhibition of c-Met/HGF signaling using a highly specific MET/Ron dual inhibitor, MK8033, worked synergistically with the combination of carboplatin plus paclitaxel to induce EOC cell growth arrest [50]. In a phase 2 randomized discontinuation trial of 70 patients with advanced EOC, cabozantinib showed an objective response rate of $21 \%$, with a median progression-free survival of 5.5 months [51]. Considering $83 \%$ of the patients received at least two prior systemic therapies and $50 \%$ of them were either platinum-refractory or resistant, these results show that cabozantinib monotherapy has a significant activity in patients with recurrent EOC. Recurrent or refractory EOC has a poor prognosis with very limited therapeutic options. Therefore, the above data suggest that MET inhibitors deserve serious consideration for clinical development by themselves or in combination with the standard chemotherapy for patients with advanced EOC.

This study has several inherent limitations. First, this meta-analysis included a small number of studies with a limited sample size. Second, all the studies were retrospectively performed. Third, as we mentioned above, the studies used different IHC methods to assess c-Met expression status. Forth, IHC criteria to stratify c-Met status were various among studies. In addition, one study did not describe the IHC criteria for c-Met overexpression. Finally, articles published only in English were included, which might bias the results.

In conclusion, this meta-analysis indicates that c-Met overexpression is an adverse prognostic marker for patients with EOC. Considering correlation between c-Met status and major pathological features failed to reach the statistical significance, however, larger studies using standardized methods and criteria for c-Met status are still needed to verify the clinicopathological impacts of high c-Met expression in EOC.

\section{Competing Interests}

The authors have declared that no competing interest exists. 


\section{References}

1. Ferlay J, Soerjomataram I, Dikshit R, Eser S, Mathers C, Rebelo M, et al. Cancer incidence and mortality worldwide: sources, methods and major patterns in GLOBOCAN 2012. Int J Cancer. 2015; 136: 359-86.

2. Siegel RL, Miller KD, Jemal A. Cancer statistics, 2016. CA Cancer J Clin. 2016; 66: 7-30.

3. Jung KW, Won YJ, Kong HJ, Lee ES; Community of Population-Based Regional Cancer Registries. Cancer statistics in Korea: incidence, mortality, survival, and prevalence in 2015. Cancer Res Treat. 2018; 50: 303-16.

4. McGuire V, Jesser CA, Whittemore AS. Survival among U.S. women with invasive epithelial ovarian cancer. Gynecol Oncol. 2002; 84: 399-403.

5. Burger RA, Brady MF, Bookman MA, Fleming GF, Monk BJ, Huang H, et al. Incorporation of bevacizumab in the primary treatment of ovarian cancer. N Engl J Med. 2011; 365: 2473-83.

6. du Bois A, Floquet A, Kim JW, Rau J, del Campo JM, Friedlander M, et al. Incorporation of pazopanib in maintenance therapy of ovarian cancer. J Clin Oncol. 2014; 32: 3374-82.

7. Ledermann J, Harter P, Gourley C, Friedlander M, Vergote I, Rustin G, et al. Olaparib maintenance therapy in platinum-sensitive relapsed ovarian cancer. N Engl J Med. 2012; 366: 1382-92.

8. Kim JH, Kim HS, Kim BJ. MET inhibitors in advanced non-small-cell lung cancer: a meta-analysis and review. Oncotarget. 2017; 8: 75500-8.

9. Blumenschein GR Jr, Mills GB, Gonzalez-Angulo AM. Targeting the hepatocyte growth factor-cMET axis in cancer therapy. J Clin Oncol. 2012; 30: 3287-96

10. Kim HJ, Yoon A, Ryu JY, Cho YJ, Choi JJ, Song SY, et al. c-MET as a potential therapeutic target in ovarian clear cell carcinoma. Sci Rep. 2016; 6: 38502.

11. Paliouras GN, Naujokas MA, Park M. Pak4, a novel Gab1 binding partner, modulates cell migration and invasion by the Met receptor. Mol Cell Biol. 2009; 29: 3018-32.

12. Furge KA, Zhang YW, Vande Woude GF. Met receptor tyrosine kinase: enhanced signaling through adapter proteins. Oncogene. 2000; 19: 5582-9.

13. Rosário $\mathrm{M}$, Birchmeier $\mathrm{W}$. How to make tubes: signaling by the Met receptor tyrosine kinase. Trends Cell Biol. 2003; 13: 328-35.

14. Zhang YW, Su Y, Volpert OV, VandeWoude GF. Hepatocyte growth factor/scatter factor mediates angiogenesis through positive VEGF and negative thrombospondin 1 regulation. Proc Natl Acad Sci USA. 2003; 100: 12718-23.

15. Ma PC, Tretiakova MS, MacKinnon AC, Ramnath N, Johnson C, Dietrich $\mathrm{S}$, et al. Expression and mutational analysis of MET in human solid cancers. Genes Chromosomes Cancer. 2008; 47: 1025-37.

16. Danilkovitch-Miagkova A, Zbar B. Dysregulation of Met receptor tyrosine kinase activity in invasive tumors. J Clin Invest. 2002; 109: 863-7.

17. Yan S, Jiao X, Zou H, Li K. Prognostic significance of c-Met in breast cancer: a meta-analysis of 6010 cases. Diagn Pathol. 2015; 10: 62.

18. Pyo JS, Kang G, Cho WJ, Choi SB. Clinicopathological significance and concordance analysis of c-MET immunohistochemistry in non-small cell lung cancers: A meta-analysis. Pathol Res Pract. 2016; 212: 710-6.

19. Yu S, Yu Y, Zhao N, Cui J, Li W, Liu T. C-Met as a prognostic marker in gastric cancer: a systematic review and meta-analysis. PLoS One. 2013; 8 : e79137.

20. Kim JH, Kim BJ, Kim HS. Clinicopathological impacts of high c-Met expression in head and neck squamous cell carcinoma: a meta-analysis and review. Oncotarget. 2017; 8: 113120-8.

21. Peng J, Qi S, Wang P, Li W, Liu C, Li F. Diagnosis and prognostic significance of c-Met in cervical cancer: a meta-analysis. Dis Markers. 2016; 2016: 6594016.

22. Kim JH, Kim HS, Kim BJ, Lee J, Jang HJ. Prognostic value of c-Met overexpression in pancreatic adenocarcinoma: a meta-analysis. Oncotarget. 2017; 8: 73098-104.

23. Kim JH, Kim HS, Kim BJ, Jang HJ, Lee J. Prognostic value of c-Met overexpression in hepatocellular carcinoma: a meta-analysis and review. Oncotarget. 2017; 8: 90351-7.

24. Kim JH, Kim BJ, Kim HS. Clinicopathological impacts of high c-Met expression in renal cell carcinoma: a meta-analysis and review. Oncotarget. 2017; 8: 75478-87.

25. Di Renzo MF, Olivero M, Katsaros D, Crepaldi T, Gaglia P, Zola P, et al. Overexpression of the Met/HGF receptor in ovarian cancer. Int J Cancer. 1994; 58: 658-62.

26. Valente G, Nicotra G, Arrondini M, Castino R, Capparuccia L, Prat M, et al. Co-expression of plexin-B1 and Met in human breast and ovary tumours enhances the risk of progression. Cell Oncol. 2009; 31: 423-36.

27. Goode EL, Chenevix-Trench G, Hartmann LC, Fridley BL, Kalli KR, Vierkant RA, et al. Assessment of hepatocyte growth factor in ovarian cancer mortality. Cancer Epidemiol Biomarkers Prev. 2011; 20: 1638-48.
28. Ayhan A, Ertunc D, Tok EC, Ayhan A. Expression of the c-Met in advanced epithelial ovarian cancer and its prognostic significance. Int J Gynecol Cancer. 2005; 15: 618-23.

29. Sawada K, Radjabi AR, Shinomiya N, Kistner E, Kenny H, Becker AR, et al. c-Met overexpression is a prognostic factor in ovarian cancer and an effective target for inhibition of peritoneal dissemination and invasion. Cancer Res. 2007; 67: 1670-9.

30. Yamamoto S, Tsuda H, Miyai K, Takano M, Tamai S, Matsubara O. Gene amplification and protein overexpression of MET are common events in ovarian clear-cell adenocarcinoma: their roles in tumor progression and prognostication of the patient. Mod Pathol. 2011; 24: 1146-55.

31. Li H, Zhang H, Zhao S, Shi Y, Yao J, Zhang Y, et al. Overexpression of MACC1 and the association with hepatocyte growth factor/c-Met in epithelial ovarian cancer. Oncol Lett. 2015; 9: 1989-96.

32. Wang H, Tan M, Zhang S, Li X, Gao J, Zhang D, et al. Expression and significance of CD44, CD47 and c-met in ovarian clear cell carcinoma. Int J Mol Sci. 2015; 16: 3391-404.

33. Battista MJ, Schmidt M, Jakobi S, Cotarelo C, Almstedt K, Heimes AS, et al. c-met is overexpressed in type I ovarian cancer: Results of an investigative analysis in a cohort of consecutive ovarian cancer patients. Oncol Lett. 2016; 12: 2001-7.

34. Puvanenthiran S, Essapen S, Haagsma B, Bagwan I, Green M, Khelwatty $\mathrm{SA}$, et al. Co-expression and prognostic significance of the HER family members, EGFRvIII, c-MET, CD44 in patients with ovarian cancer. Oncotarget. 2018; 9: 19662-74.

35. Panic N, Leoncini E, de Belvis G, Ricciardi W, Boccia S. Evaluation of the endorsement of the preferred reporting items for systematic reviews and meta-analysis (PRISMA) statement on the quality of published systematic review and meta-analyses. PLoS One. 2013; 8: e83138.

36. Sterne JA, Sutton AJ, Ioannidis JP, Terrin N, Jones DR, Lau J, et al. Recommendations for examining and interpreting funnel plot asymmetry in meta-analyses of randomised controlled trials. BMJ. 2011; 343: $\mathrm{d} 4002$.

37. Eagger M, Davey Smith G, Schneider M, Minder C. Bias in meta-analysis detected by a simple graphical test. BMJ. 1997; 315: 629-34.

38. Tang C, Jardim DL, Falchook GS, Hess K, Fu S, Wheler JJ, et al. MET nucleotide variations and amplification in advanced ovarian cancer: characteristics and outcomes with c-Met inhibitors. Oncoscience. 2013; 1: 5-13.

39. Lorenzato A, Olivero M, Patanè S, Rosso E, Oliaro A, Comoglio PM, et al. Novel somatic mutations of the MET oncogene in human carcinoma metastases activating cell motility and invasion. Cancer Res. 2002; 62: 7025-30.

40. Gherardi E, Birchmeier W, Birchmeier C, Vande Woude G. Targeting MET in cancer: rationale and progress. Nat Rev Cancer. 2012; 12: 89-103.

41. Singer G, Oldt R 3rd, Cohen Y, Wang BG, Sidransky D, Kurman RJ, et al. Mutations in BRAF and KRAS characterize the development of low-grade ovarian serous carcinoma. J Natl Cancer Inst. 2003; 95: 484-6.

42. Landen CN Jr, Birrer MJ, Sood AK. Early events in the pathogenesis of epithelial ovarian cancer. J Clin Oncol. 2008; 26: 995-1005.

43. Levanon K, Crum C, Drapkin R. New insights into the pathogenesis of serous ovarian cancer and its clinical impact. J Clin Oncol. 2008; 26: 5284-93.

44. Peters S, Adjei AA. MET: a promising anticancer therapeutic target. Nat Rev Clin Oncol. 2012; 9: 314-26.

45. Santoro A, Rimassa L, Borbath I, Daniele B, Salvagni S, Van Laethem JL, et al. Tivantinib for second-line treatment of advanced hepatocellular carcinoma: a randomised, placebo-controlled phase 2 study. Lancet Oncol. 2013; 14: 55-63.

46. Xiang $Q$, Chen $\mathrm{W}$, Ren $\mathrm{M}$, Wang J, Zhang H, Deng DY, et al. Cabozantinib suppresses tumor growth and metastasis in hepatocellular carcinoma by a dual blockade of VEGFR2 and MET. Clin Cancer Res. 2014; 20: 2959-70

47. Choueiri TK, Escudier B, Powles T, Tannir NM, Mainwaring PN, Rini BI, et al. Cabozantinib versus everolimus in advanced renal cell carcinoma (METEOR): final results from a randomised, open-label, phase 3 trial. Lancet Oncol. 2016; 17: 917-27.

48. Scagliotti G, von Pawel J, Novello S, Ramlau R, Favaretto A, Barlesi F, et al. Phase III multinational, randomized, double-blind, placebo-controlled study of tivantinib (ARQ 197) plus erlotinib versus erlotinib alone in previously treated patients with locally advanced or metastatic nonsquamous non-small-cell lung cancer. J Clin Oncol. 2015; 33: $2667-74$

49. Tang MK, Zhou HY, Yam JW, Wong AS. c-Met overexpression contributes to the acquired apoptotic resistance of nonadherent ovarian cancer cells through a cross talk mediated by phosphatidylinositol 3-kinase and extracellular signal-regulated kinase 1/2. Neoplasia. 2010; 12: $128-38$. 
50. Marchion DC, Bicaku E, Xiong Y, Bou Zgheib N, Al Sawah E, Stickles XB, et al. A novel c-Met inhibitor, MK8033, synergizes with carboplatin plus paclitaxel to inhibit ovarian cancer cell growth. Oncol Rep. 2013; 29: 2011-8.

51. Vergote IB, Smith DC, Berger R, Kurzrock R, Vogelzang NJ, Sella A, et al. A phase 2 randomised discontinuation trial of cabozantinib in patients with ovarian carcinoma. Eur J Cancer. 2017; 83: 229-36. 